American J. of Engineering and Applied Sciences 2 (3): 515-525, 2009

ISSN 1941-7020

(C) 2009 Science Publications

\title{
Estimation of Earthquake-Induced Crest Settlements of Embankments
}

\author{
Raghvendra Singh and Debasis Roy \\ Department of Civil Engineering, Indian Institute of Technology Kharagpur, WB 721302, India
}

\begin{abstract}
Problem statement: Freeboard requirement, a major consideration in the design of embankment dams, is controlled to a great extent by the crest settlements during earthquakes. Approach: The parameters that influence earthquake induced crest settlement had been studied using 152 published case histories on performance of embankment dams during earthquakes. Results: Based on the results a correlation had been proposed for obtaining preliminary estimates of earthquakeinduced crest settlements. The correlation used the ratio of the peak horizontal ground acceleration and the yield acceleration as the estimator. Conclusion/Recommendations: The database analysis also indicated that crest settlements are larger where the fundamental periods of the embankment were similar to the predominant periods of the earthquake. Earthquake magnitude and the vertical component of earthquake ground motion, on the other hand, appeared to have a small influence on crest settlement.
\end{abstract}

Key words: Peak horizontal ground acceleration, dams, embankments, earthquake, fundamental period, predominant period

\section{INTRODUCTION}

Earthquake-induced deformations of embankment dams are commonly estimated from the sliding block procedure $^{[35]}$. In this procedure the yield acceleration, $\mathrm{a}_{\mathrm{y}}$, or the horizontal seismic coefficient that gives a pseudo static limit equilibrium factor of safety of unity against slope failure is first estimated from pseudo static slope stability analyses. The pseudo static slope stability analysis is essentially an extension of conventional, static stability analysis in that it approximately accounts for the inertial effects by using inertial forces in proportion of horizontal and vertical seismic coefficients depending on the ground acceleration levels representing the design earthquake. In the sliding block approach the permanent deformation is estimated for a particular earthquake acceleration time history by identifying the time intervals over which the down slope earthquake acceleration exceeds $a_{y}$ and doubly integrating the difference between the down slope earthquake acceleration and $\mathrm{a}_{\mathrm{y}}$ over these intervals considering rigid plastic material behavior and inertia-related overshooting. A slope is usually assumed to be stable during earthquakes if the estimated down slope deformation is smaller than $1 \mathrm{~m}$.

As in pseudo static method, the sliding block method assumes the sliding wedge (the volume of soil above the slip surface) to be rigid plastic whereas in reality the soil is flexible. Also contrary to the assumption of these methods that the cohesivefrictional strength between the sliding wedge and the soil mass below do not degrade with continued earthquake shaking, loose or soft soils tend to soften during earthquakes because of development of pore water pressure. Another difficulty with the use of sliding block method is the need for a suite of design earthquake acceleration time histories, which, in many cases, is not available. Nevertheless because of the simplicity of these methods, they often are the procedures of choice in a preliminary design project.

Semi empirical or performance-based charts have been developed, e.g., Singh et al. ${ }^{[49]}$ for obtaining preliminary estimates of permanent, earthquake-induced deformation of earth dams and embankments from the results of limit-equilibrium, pseudo-static slope stability assessment in situations where site specific design earthquake acceleration time histories are unavailable ${ }^{[17,26,45]}$. The procedure developed by the Hynes-Griffin and Franklin ${ }^{[17]}$, for instance, extends the Newmark ${ }^{[35]}$ sliding block method relating the deformation of dam section to the ratio of yield acceleration, $\mathrm{a}_{\mathrm{y}}$ and the peak horizontal ground acceleration at dam base, $a_{\max }$ based on stability assessments of slopes for a large number of natural and synthetic earthquake acceleration time

Corresponding Author: Debasis Roy, Department of Civil Engineering, Indian Institute of Technology Kharagpur, WB 721302, India Tel: 913222 283456/91 9333451843 Fax: 913222282254 
Am. J. Engg. \& Applied Sci., 2 (3): 515-525, 2009

histories. Singh et al. ${ }^{[49]}$, on the other hand, related permanent down slope deformation to $\mathrm{a}_{\mathrm{y}} / \mathrm{a}_{\max }$ based on dam performance observations from past earthquakes.

Unfortunately, these procedures based on the sliding block approach are generally silent about the physical significance of the representative permanent down slope displacements. Assuming the down slope displacement to align with the average inclination of the base of the critical slip surface, crest settlement could however be roughly estimated from the down slope displacement obtained from the sliding block procedures $^{[49]}$. The confusion in this regard can be avoided to a great extent by developing a framework for direct estimation of crest settlement.

Swaisgood ${ }^{[53]}$ studied the factors that influence crest settlement using 70 incidents of performance of embankments or dams in past earthquakes and proposed a relationship between estimated crest deformation and the peak horizontal ground acceleration. In essence, the approach is based on a family of relationships between observed crest settlement and peak ground acceleration that depend on earthquake magnitude. Although crest settlements are expected to be smaller for embankment dams constructed with or underlain by stronger materials, the approach did not consider material strength as a parameter of significance. Possible influence of the relationship between the fundamental period of the structure and the predominant frequency of the earthquake on crest settlement was also not examined.

In this article an attempt has been made to identify the parameters that influence earthquake-related crest settlement, $\Delta$ and develop a simple procedure for estimating $\Delta$. The study is based on observational records on performance of embankment dams during past earthquakes and the proposed procedure for estimating crest settlement approximately accounts for the strength of materials within and underneath the dam body as well as the intensity of the earthquake. The case histories used in this study pertain to earthquakes of magnitudes between 4.5 and 8.3 , peak horizontal ground accelerations between 0.02 and $0.90 \mathrm{~g}$ and a wide variety of earth structures such as single zone earth embankments, multi-zone earth and rock fill dams for retaining water, Concrete Face Rock Fill Dams (CFRDs) and tailings dams (Table 1).

Table 1: Case history listing

\begin{tabular}{|c|c|c|c|c|}
\hline Dam, type, height (m) & $\begin{array}{l}\text { Earthquake: Date, } \mathrm{M}_{\mathrm{w}}, \\
\mathrm{a}_{\max }(\mathrm{g}) \text {, Dist. }(\mathrm{km}), \mathrm{T}_{\mathrm{p}}(\mathrm{s})\end{array}$ & $\begin{array}{l}T_{D}(s), a_{y}(w / o \text { and } \\
\left.\text { with vert. } \operatorname{acc}^{\mathrm{n}}\right)(g)\end{array}$ & $\Delta(\mathrm{m})$ & Reference \\
\hline Anderson, $8,73.2$ & $10 / 17 / 89,7.0,0.26,16,0.32$ & $1.08,0.34,0.24$ & 0.0410 & Harder $^{[16]}$ \\
\hline Anderson, 8, 71.6 & $4 / 24 / 84,6.2,0.41,16,0.32$ & $1.08,0.27,0.20$ & 0.0140 & Bureau et al. ${ }^{[6]}$ \\
\hline Artichoke, $2,4.0$ & $10 / 17 / 89,7.1,0.33,27,0.32$ & $0.08,0.28,0.21$ & 0.6000 & Miller and Roycroft ${ }^{[31,32]}$ \\
\hline Austrian, $7,21.5$ & $10 / 17 / 89,7.0,0.58,11,0.32$ & $0.79,0.21,0.17$ & 0.7890 & $\operatorname{Harder}^{[16]}$ \\
\hline Asagawara regulatory, $7,56.4$ & $10 / 23 / 04,6.8,0.12,24,0.32$ & $0.53,0.08,0.07$ & 0.7000 & Yasuda et al. ${ }^{[55]}$ \\
\hline Baihe, $7,66.0$ & $7 / 28 / 76,7.8,0.20,150,0.52$ & $0.89,0.06,0.06$ & 2.5000 & Lingyao et al..$^{[25]}$ \\
\hline Bouquet Canyon, 5, 62.0 & $7 / 21 / 52,7.3,0.12,74,0.40$ & $0.54,0.16,0.14$ & 0.0010 & Seed et $_{\text {al }}{ }^{[48]}$ \\
\hline Brea, $7,27.4$ & $1 / 17 / 94,6.9,0.19,67,0.45$ & $0.76,0.25,0.17$ & 0.0010 & Abdel-Ghaffar and Scott ${ }^{[1]}$ \\
\hline Buena Vista, 5, 6.0 & $7 / 21 / 52,7.3,0.30,32,0.32$ & $0.45,0.16,0.13$ & 0.6000 & Seed et al..$^{[48]}$ \\
\hline Chabbot, $5,43.3$ & $4 / 18 / 06,8.3,0.57,32,0.32$ & $0.99,0.12,0.11$ & 0.4500 & Makdisi and Seed ${ }^{[26]}$ \\
\hline Chabbot, $5,43.3$ & $10 / 17 / 89,7.0,0.10,60,0.32$ & $0.99,0.12,0.11$ & 0.0010 & Makdisi and Seed ${ }^{[26]}$ \\
\hline Chang, $7,15.5$ & $1 / 26 / 01,7.6,0.50,13,0.32$ & $0.25,0.05,0.05$ & 2.6400 & Singh et al. ${ }^{[50]}$ \\
\hline Chofukuji, 7, 27.2 & $10 / 23 / 04,6.8,0.10,21,0.32$ & $0.38,0.09,0.08$ & 0.0700 & Yasuda et al. ${ }^{[55]}$ \\
\hline Chonan, 4, 6.1 & $12 / 17 / 87,6.7,0.12,40,0.32$ & $0.11,0.01,0.01$ & 3.8700 & Ishihara et al. ${ }^{[20]}$ \\
\hline Cogoti D/S, 9, 85.0 & $4 / 4 / 43,7.9,0.19,89,0.60$ & $0.83,0.28,0.23$ & 0.3500 & Arrau et al..$^{[3]}$ \\
\hline Cogoti D/S, 9, 85.0 & $3 / 28 / 65,7.1,0.04,153,0.55$ & $0.83,0.28,0.24$ & 0.0010 & Arrau et $a l . .^{[3]}$ \\
\hline Cogoti D/S, $9,85.0$ & $7 / 8 / 75,7.5,0.05,165,0.57$ & $0.83,0.28,0.24$ & 0.0010 & Arrau et $a l . .^{[3]}$ \\
\hline Cogoti D/S, 9, 85.0 & $3 / 8 / 85,7.7,0.03,280,0.96$ & $0.83,0.28,0.24$ & 0.0010 & Arrau et al. ${ }^{[3]}$ \\
\hline Cogswell, $9,85.0$ & $10 / 1 / 87,6.0,0.06,29,0.25$ & $0.69,0.13,0.11$ & 0.0010 & Boulanger et al. ${ }^{[5]}$ \\
\hline Cogswell, 9, 8.50 & $6 / 28 / 91,5.6,0.26,4,0.25$ & $0.69,0.15,0.14$ & 0.0160 & Boulanger et $a l^{[5]}$ \\
\hline Demi $1,7,17.0$ & $1 / 26 / 01,7.6,0.20,90,0.55$ & $0.23,0.26,0.24$ & 0.0500 & Krinitzsky and Hynes ${ }^{[23]}$ \\
\hline Douhe, $4,16.0$ & $7 / 28 / 76,7.8,0.90,20,0.30$ & $0.22,0.34,0.24$ & 1.6400 & $\operatorname{Yen}^{[60]}$ \\
\hline Dry Canyon, 5, 22.0 & $7 / 21 / 52,7.3,0.12,72,0.28$ & $0.65,0.12,0.10$ & 0.0300 & Seed et $_{\text {al }}^{\left[{ }^{448]}\right.}$ \\
\hline El Cobre, $12,32.5$ & $3 / 28 / 65,7.2,0.80,40,0.32$ & $0.49,0.00,0.00$ & 32.000 & Dobry and Alvarez ${ }^{[10]}$ \\
\hline El Infiernillo D/S, 8, 148.0 & $3 / 14 / 79,7.6,0.23,110,0.55$ & $1.58,0.55,0.39$ & 0.0460 & Resendiz et al. ${ }^{[43]}$ \\
\hline El Infiernillo U/S, 8, 146.0 & $10 / 11 / 75,5.9,0.08,79,0.34$ & $1.58,0.08,0.08$ & 0.0400 & Swaisgood ${ }^{[53]}$ \\
\hline El Infiernillo U/S, 8, 146.0 & $11 / 15 / 75,7.5,0.09,23,0.32$ & $1.58,0.09,0.08$ & 0.0200 & Swaisgood $^{[53]}$ \\
\hline El Infiernillo U/S, 8, 148.0 & $3 / 14 / 79,7.6,0.23,110,0.55$ & $1.58,0.19,0.18$ & 0.1280 & Resendiz et al. ${ }^{[43]}$ \\
\hline El Infiernillo U/S, 8, 146.0 & $10 / 25 / 81,7.3,0.05,81,0.34$ & $1.58,0.05,0.03$ & 0.0600 & Swaisgood $^{[53]}$ \\
\hline El Infiernillo U/S, 8, 146.0 & $9 / 19 / 85,8.1,0.13,76,0.53$ & $1.58,0.11,0.10$ & 0.1100 & Swaisgood $^{[53]}$ \\
\hline El Infiernillo U/S, 8, 148.0 & $9 / 19 / 89,8.1,0.20,113,0.70$ & $1.58,0.13,0.12$ & 0.0490 & Resendiz et al..$^{[43]}$ \\
\hline El Infiernillo U/S, 8, 148.0 & $9 / 21 / 89,7.2,0.12,116,0.56$ & $1.58,0.13,0.12$ & 0.0650 & Resendiz et al. ${ }^{[43]}$ \\
\hline El Khattabi, 10, 27.5 & $2 / 24 / 04,6.4,0.25,21,0.25$ & $0.37,0.18,0.16$ & 0.0100 & EERI $^{[14]}$ \\
\hline EJ Chesbro, 7, 29.0 & $4 / 24 / 84,6.2,0.18,22,0.32$ & $0.37,0.14,0.13$ & 0.0200 & Swaisgood $^{[53]}$ \\
\hline
\end{tabular}


Am. J. Engg. \& Applied Sci., 2 (3): 515-525, 2009

Table 1: Continue

EJ Chesbro, 7, 29.0

Fairmont, 5, 40.0

Fatehgadh, 7, 11.6

Gongen, 8, 32.6

Guadalupe, 7, 43.3

Guldurek, 7, 68.0

Hachiro Gata, 4, 4.0

Hawkins, 6, 22.0

Hebgen, 7, 27.5

Hokkaido tailings, 12, 9.2

Idenoshiri-Ike, 5, 5.5

Industrial, 2, 8.0

Ishibuchi, 9, 53.0

Kalaghoda, 7, 14.9

Kalpong, 9, 27.0

Kanayatani, 10, 4.0

Kashi, 7, 16.0

Kashi, 7, 16.0

Kaswati, 7, 12

Kawanishi, 7, 43.0

Kitayama, 7, 25.0

Kodanuma, 4, 2.5

Kushiro Dike, 1, 6.4

La Marquesa, 7, 10.0

La Palma, 7, 10.0

La Villita, 8, 60.0

La Villita, 8, 60.0

La Villita, 8, 60.0

La Villita, 8, 60.0

La Villita, 8, 60.0

La Villita, 8, 60.0

Lake Merced, 4, 12.5

Lake Temes, 3, 35.0

Lexington, 7, 62.5

Long Valley, 7, 38.4

Lake Franklin, 5, 31.0

Lower Van Norman, 7, 24.0

Lower San Fernando, 6, 32.8

Lower San Fernando, 6, 32.8

LA dam, 7, 47.3

Mahgoan, 3, 16.9

Makubetsu, 7, 26.9

Matahina, 8, 86.0

Matiyari, 3, 29.0

May 1 Slide, 11, 32.0

Metoki, 4, 5.0

Miboro, 8, 131.0

Miho, 8, 95.0

Miho, 8, 95.0

Miho, 8, 95.0

Miho, 8, 95.0

Miho, 8, 95.0

Miho, 8, 95.0

Mill Creek, 6, 23.2

Minase, 9, 67.0

Minoogawa, 8, 47.0

Mochikoshi 1, 12, 30.0

Mochikoshi 2, 12, 22.0

Murayama, 7, 39.0

Muraya-kami, 7, 24.0

Muraya-shino, 7, 30.0

Nalband, 4, 4.0

Newell, 8, 55.5

Niteko Loer, 3, 12.0

Niteko middle, 3, 10.0

Niteko upper, 3, 10.0

Niwa Ikumine, 7, 15.0

North Dike, 36.0
$10 / 17 / 89,7.0,0.43,13,0.32$

$7 / 21 / 52,7.3,0.18,36,0.32$

$1 / 26 / 01,7.6,0.30,80,0.55$

$1 / 17 / 95,8.2,0.11,28,0.32$

$10 / 17 / 89,7.0,0.43,19,0.32$

$6 / 6 / 00,5.9,0.13,19,0.27$

$5 / 26 / 83,7.7,0.17,95,0.60$

$10 / 17 / 89,7.0,0.23,34,0.32$

$8 / 17 / 59,7.5,0.70,100,0.65$

$5 / 16 / 68,7.9,0.23,18,0.60$

$1 / 17 / 95,7.1,0.44,10,0.32$

$10 / 17 / 89,7.1,0.33,18,0.32$

$5 / 26 / 03,7.1,0.27,85,0.42$

1/26/01, 7.6, 0.30, 65, 0.47

$9 / 14 / 02,6.5,0.10,21,0.27$

$10 / 6 / 00,7.3,0.11,14,0.32$

$8 / 23 / 85,7.4,0.25,21,0.32$

$9 / 12 / 85,6.8,0.50,16,0.30$

$1 / 26 / 01,7.6,0.28,110,0.60$

$10 / 23 / 04,6.8,0.14,17,0.32$

$1 / 17 / 95,7.1,0.30,31,0.32$

$5 / 16 / 68,7.9,0.23,-, 0.27$

$1 / 15 / 93,7.8,0.20,19,0.32$

$3 / 3 / 85,7.8,0.67,45,0.40$

$3 / 3 / 85,7.8,0.46,80,0.38$

$11 / 15 / 75,5.9,0.08,10,0.25$

$10 / 11 / 75,4.9,0.15,52,0.27$

3/14/79, 7.6, 0.100, 11, 0.55

$10 / 25 / 81,7.3,0.17,121,0.60$

$9 / 19 / 85,8.1,0.24,58,0.48$

$9 / 21 / 85,7.5,0.04,61,0.32$

$3 / 22 / 57,5.3,0.12,5,0.32$

4/18/06, 7.6, 0.35, 2, 0.4

$10 / 17 / 89,7.0,0.45,10,0.32$

$5 / 27 / 80,6.1,0.20,16,0.25$

$1 / 17 / 94,6.7,0.30,18,0.25$

$2 / 9 / 71,6.6,0.60,13,0.27$

$2 / 9 / 71,6.6,0.45,8,0.27$

$1 / 17 / 94,6.9,0.32,11,0.32$

$1 / 17 / 94,6.9,0.43,7,0.32$

$5 / 22 / 97,6.0,0.50,38,0.25$

$9 / 26 / 03,8.0,0.25,141,0.50$

$3 / 2 / 87,6.5,0.24,11,0.28$

$5 / 22 / 97,6.0,0.45,95,0.27$

$1 / 23 / 89,5.5,0.15,3,0.25$

$5 / 16 / 68,7.9,0.23,180,0.32$

$8 / 19 / 61,7.0,0.15,16,0.32$

$1 / 29 / 80,6.6,0.03,57,0.33$

4/14/81, 4.5, 0.03, 13, 0.32

$8 / 8 / 83,6.0,0.15,12,0.25$

$12 / 17 / 87,6.6,0.01,131,0.6$

$8 / 5 / 90,5.1,0.03,24,0.25$

$2 / 2 / 92,5.7,0.01,73,0.32$

$10 / 17 / 89,7.0,0.28,29,0.32$

$6 / 16 / 64,7.5,0.08,145,0.77$

$1 / 17 / 95,7.1,0.14,48,0.34$

$1 / 14 / 78,7.0,0.25,8,0.32$

$1 / 14 / 78,7.0,0.25,8,0.32$

$9 / 1 / 23,8.2,0.80,96,0.60$

$9 / 1 / 23,8.2,0.80,75,0.60$

$9 / 1 / 23,8.2,0.80,85,0.60$

$12 / 7 / 88,6.8,0.75,28,0.32$

$10 / 17 / 89,7.0,0.43,10,0.32$

1/17/95, 6.9, 0.40, 4, 0.32

$1 / 17 / 95,6.9,0.40,4,0.32$

$1 / 17 / 95,6.9,0.40,4,0.32$

$7 / 12 / 93,7.8,0.28,71,0.36$

$1 / 17 / 94,6.7,0.43,9,0.32$
$0.46,0.15,0.13$

$0.54,0.11,0.09$

$0.28,0.07,0.07$

$0.40,0.46,0.32$

$0.68,0.19,0.16$

$0.91,0.27,0.20$

$0.08,0.00,0.00$

$0.15,0.30,0.22$

$0.47,0.22,0.20$

$0.14,0.00,0.00$

$0.65,0.11,0.09$

$0.12,0.35,0.25$

$0.63,0.28,0.23$

$0.18,0.29,0.24$

$0.35,0.10,0.09$

$0.05,0.04,0.04$

$0.25,0.14,0.12$

$0.25,0.14,0.12$

$0.33,0.15,0.14$

$0.59,0.14,0.13$

$0.34,0.15,0.13$

$0.05,0.00,0.00$

$0.11,0.04,0.06$

$0.11,0.02,0.02$

$0.12,0.05,0.04$

$0.94,0.20,0.15$

$0.94,0.20,0.17$

$0.94,0.30,0.19$

$0.94,0.20,0.18$

$0.94,0.20,0.17$

$0.94,0.20,0.18$

$0.27,0.00,0.00$

$0.60,0.10,0.08$

$0.77,0.13,0.09$

$0.52,0.23,0.17$

$-, 0.28,0.20$

$0.38,0.19,0.15$

$0.48,0.00,0.00$

$0.48,0.15,0.14$

$0.60,0.15,0.13$

$0.52,0.29,0.19$

$0.42,0.18,0.17$

$1.08,0.17,0.14$

$0.49,0.27,0.18$

$0.37,0.00,0.00$

$0.14,0.00,0.00$

$1.43,0.23,0.16$

$1.22,0.23,0.10$

$1.22,0.23,0.17$

$1.22,0.23,0.17$

$1.22,0.23,0.20$

$1.22,0.23,0.17$

$1.22,0.23,0.19$

$0.30,0.14,0.12$

$0.72,0.14,0.10$

$0.57,0.49,0.40$

$0.42,0.00,0.00$

$0.42,0.00,0.00$

$0.52,0.29,0.24$

$0.52,0.14,0.11$

$0.52,0.11,0.10$

$0.24,0.00,0.00$

$0.75,0.25,0.18$

$0.21,0.07,0.06$

$0.17,0.04,0.04$

$0.17,0.04,0.04$

$0.23,0.07,0.04$

$0.45,0.11,0.09$

\begin{tabular}{|c|c|}
\hline 0.1130 & $\operatorname{Harder}^{[16]}$ \\
\hline 0.0010 & Seed et al..$^{[48]}$ \\
\hline 1.0300 & Singh et al. ${ }^{[50]}$ \\
\hline 0.0010 & Matsumoto et al. ${ }^{[27]}$ \\
\hline 0.1950 & $\operatorname{Harder}^{[16]}$ \\
\hline 0.0200 & Ozkan and Aksar ${ }^{[40]}$ \\
\hline 2.5400 & Olson $^{[38]}$ \\
\hline 0.0010 & Harder $^{[16]}$ \\
\hline 1.9200 & Seed et al..$^{[48]}$ \\
\hline 12.500 & Ishihara et al. ${ }^{[21]}$ \\
\hline 4.0000 & Uchida et al $^{[56]}$ \\
\hline 0.4000 & Miller and Roycroft ${ }^{[31,32]}$ \\
\hline 0.0010 & Nagayama et al. ${ }^{[34]}$ \\
\hline 0.0250 & Krinitzsky and Hynes $^{[23]}$ \\
\hline 0.0010 & Rai and Murty ${ }^{[42]^{]}}$ \\
\hline 0.7500 & Matsuo $^{[28]}$ \\
\hline 0.4000 & Chonggang $^{[8]}$ \\
\hline 1.5000 & Chonggang ${ }^{[8]}$ \\
\hline 1.2100 & Singh et al. ${ }^{[50]}$ \\
\hline 0.3000 & Yasuda et al ${ }^{[55]}$ \\
\hline 0.7500 & Sakamoto et al..$^{[44]}$ \\
\hline 1.2900 & Mishima and Kimura $^{[30]}$ \\
\hline 2.0000 & Sasaki et al..$^{[46]}$ \\
\hline 2.0500 & De Alba et al..$^{[9]}$ \\
\hline 0.6100 & De Alba et al..$^{[9]}$ \\
\hline 0.0240 & Elgamal et al. ${ }^{[11]}$ \\
\hline 0.0240 & Elgamal et al. ${ }^{[11]}$ \\
\hline 0.0130 & Elgamal et al. ${ }^{[11]}$ \\
\hline 0.1140 & Elgamal et al $^{[11]}$ \\
\hline 0.3360 & Elgamal et al. ${ }^{[1]]}$ \\
\hline 0.1200 & Swaisgood $^{[53]}$ \\
\hline 6.6600 & Olson $^{[38]}$ \\
\hline 0.0100 & Seed et al..$^{[48]}$ \\
\hline 0.2590 & $\operatorname{Harder}^{[16]}$ \\
\hline 0.0010 & Lai and Seed ${ }^{[24]}$ \\
\hline 0.0500 & Seed et al. ${ }^{[48]}$ \\
\hline 0.1440 & Chaney $^{[7]}$ \\
\hline 7.9500 & Seed et al..$^{[47]}$ \\
\hline 0.1500 & Bardet and Davis ${ }^{[4]}$ \\
\hline 0.0880 & Seed $e^{\prime} a l .{ }^{[48]}$ \\
\hline 0.0200 & $\mathrm{EERI}^{[12]}$ \\
\hline 0.5000 & Nagayama et al. ${ }^{[34]}$ \\
\hline 0.0990 & Pender and Robertson ${ }^{[41]}$ \\
\hline 0.0100 & $\mathrm{EERI}^{[12]}$ \\
\hline 5.9200 & Ishihara et al. ${ }^{[21]}$ \\
\hline 5.0000 & Ishihara et al. ${ }^{[21]}$ \\
\hline 0.0260 & Bureau et al. ${ }^{[6]}$ \\
\hline 0.0010 & Iwashita et al. ${ }^{[22]}$ \\
\hline 0.0010 & Iwashita et al. ${ }^{[22]}$ \\
\hline 0.0010 & Iwashita et al. ${ }^{[22]}$ \\
\hline 0.0010 & Iwashita et al. ${ }^{[22]}$ \\
\hline 0.0010 & Iwashita et al..$^{[22]}$ \\
\hline 0.0010 & Iwashita et al..$^{[22]}$ \\
\hline 0.0150 & Harder $^{[16]}$ \\
\hline 0.0600 & Swaisgood $^{[53]}$ \\
\hline 0.0010 & Matsumoto et al. ${ }^{[27]}$ \\
\hline 22.750 & Okusa and Anma ${ }^{[36]}$ \\
\hline 15.900 & Okusa and $\mathrm{Anma}^{[36]}$ \\
\hline 1.2000 & Seed et al. ${ }^{[48]}$ \\
\hline 0.1800 & Stroite $^{[52]}$ \\
\hline 0.0010 & Stroitel $^{[52]}$ \\
\hline 3.0000 & Yegian et al. ${ }^{[58]}$ \\
\hline 0.0110 & Harder $^{[16]}$ \\
\hline 2.0000 & Sitar ${ }^{[51]}$ \\
\hline 2.7000 & $\operatorname{Sitar}_{[5]}^{[51]}$ \\
\hline 2.7000 & $\operatorname{Sitar}^{[51]}$ \\
\hline 1.7500 & $\operatorname{Tani}^{[54]}$ \\
\hline 0.0300 & Swaisgood $^{[53]}$ \\
\hline
\end{tabular}


Am. J. Engg. \& Applied Sci., 2 (3): 515-525, 2009

Table 1: Continue

\begin{tabular}{|c|c|c|c|c|}
\hline O’ Neil, 3, 21.3 & $10 / 17 / 89,7.0,0.11,59,0.33$ & $0.37,0.17,0.14$ & 0.0010 & Harder $^{[16]}$ \\
\hline Ono, $7,36.6$ & $9 / 1 / 23,8.2,0.80,96,0.60$ & $0.52,0.27,0.24$ & 0.3050 & Seed et $a l .^{[48]}$ \\
\hline Oya, $8,40.5$ & $12 / 8 / 93,5.0,0.004,42,0.26$ & $0.51,0.20,0.16$ & 0.0010 & Iwashita et al..$^{[22]}$ \\
\hline Oya, $8,40.5$ & $2 / 16 / 93,5.0,0.01,28,0.25$ & $0.51,0.20,0.16$ & 0.0010 & Iwashita et al. ${ }^{[22]}$ \\
\hline Oya, $8,40.5$ & $2 / 2 / 93,4.8,0.02,9,0.25$ & $0.51,0.20,0.15$ & 0.0010 & Iwashita et al. ${ }^{[22]}$ \\
\hline Oya, $8,40.5$ & $2 / 7 / 93,6.5,0.07,31,0.28$ & $0.51,0.20,0.16$ & 0.0010 & Iwashita et al..$^{[22]}$ \\
\hline Oya, $8,40.5$ & $2 / 8 / 93,4.9,0.007,37,0.25$ & $0.51,0.20,0.16$ & 0.0010 & Iwashita et al. ${ }^{[22]}$ \\
\hline Ova, $8,40.5$ & $6 / 7 / 94,4.9,0.005,40,0.25$ & $0.51,0.20,0.16$ & 0.0010 & Iwashita et al..$^{[22]}$ \\
\hline Oroville, $7,235.0$ & $8 / 1 / 75,6.0,0.11,7,0.25$ & $2.74,0.21,0.13$ & 0.0070 & Bureau et al..$^{[6]}$ \\
\hline Otani-Ike, 7, 27.0 & $12 / 21 / 46,8.3,0.80,45,0.32$ & $0.65,0.15,0.12$ & 0.0010 & Stroitel ${ }^{[52]}$ \\
\hline Piedmont, $3,17.0$ & $4 / 18 / 06,7.6,0.35,18,0.40$ & $0.60,0.14,0.13$ & 0.2000 & Seed et $_{\text {al }}^{[48]}$ \\
\hline Route $272,4,7.5$ & $1 / 15 / 93,7.8,0.38,20,0.40$ & $0.13,0.00,0.00$ & 5.2500 & Miura et al..$^{[33]}$ \\
\hline Rudramata, 7, 27.6 & $1 / 26 / 01,7.6,0.30,80,0.55$ & $0.28,0.07,0.07$ & 0.8300 & Singh et al. ${ }^{[50]}$ \\
\hline San Andreas, 3, 32.0 & $4 / 18 / 06,7.6,0.80,2,0.40$ & $0.60,0.11,0.09$ & 0.0010 & Seed et al..$^{[48]}$ \\
\hline San Justo, $8,41.0$ & $10 / 17 / 89,7.0,0.26,27,0.32$ & $0.51,0.27,0.21$ & 0.0010 & Harder ${ }^{[16]}$ \\
\hline San Luis, 3, 93.0 & $10 / 17 / 89,7.0,0.06,54,0.33$ & $1.32,0.09,0.09$ & 0.0010 & Harder $^{[16]}$ \\
\hline Santa Flacia, 6, 65.0 & $1 / 17 / 94,6.7,0.18,33,0.25$ & $0.82,0.17,0.12$ & 0.0200 & Swaisgood ${ }^{[53]}$ \\
\hline Santa Flacia, 6, 72.0 & $9 / 2 / 71,6.6,0.11,10,0.25$ & $0.78,0.10,0.08$ & 0.0200 & Abdel-Ghaffar and $\operatorname{Scott}^{[1]}$ \\
\hline Santa Flacia, 6, 72.0 & $4 / 8 / 76,4.6,0.05,14,0.25$ & $0.78,0.05,0.04$ & 0.0100 & Abdel-Ghaffar and Scott ${ }^{[1]}$ \\
\hline Sasoi, $7,20.0$ & $1 / 26 / 01,7.6,0.20,120,0.63$ & $0.27,0.30,0.28$ & 0.0250 & Krinitzsky and Hynes ${ }^{[23]}$ \\
\hline Shibecha Cho, 4, 9.5 & $1 / 15 / 93,7.8,0.38,40,0.40$ & $0.16,0.00,0.00$ & 9.2600 & Miura et al. ${ }^{[33]}$ \\
\hline Shin-Yamam., $8,44.5$ & $10 / 23 / 04,6.8,0.55,6,0.32$ & $0.56,0.36,0.24$ & 0.0200 & Yasuda et al.$^{[55]}$ \\
\hline Shiribeshi Toshibetsu Dike 1, 1, 6.5 & $7 / 12 / 93,7.8,0.18,100,0.60$ & $0.09,0.04,0.04$ & 2.7000 & Ozutsumi et al..$^{[40]}$ \\
\hline Shiribeshi Toshibetsu Dike 2, $1,4.5$ & $7 / 12 / 93,7.8,0.18,100,0.60$ & $0.07,0.08,0.08$ & 1.2600 & Ozutsumi et al. ${ }^{[40]}$ \\
\hline Shiribeshi Toshibetsu Dike 3, 1, 4.6 & $7 / 12 / 93,7.8,0.18,100,0.60$ & $0.07,0.12,0.09$ & 0.6300 & Ozutsumi et al. ${ }^{[40]}$ \\
\hline Shivlakha, $7,18.0$ & $1 / 26 / 01,7.6,0.45,28,0.32$ & $0.26,0.23,0.21$ & 1.6200 & Singh et al. ${ }^{[50]}$ \\
\hline Soda Lake, 13, 10.7 & $10 / 17 / 89,7.0,0.33,29,0.32$ & $0.19,0.16,0.15$ & 0.6000 & Miller and Roycroft ${ }^{[31,32]}$ \\
\hline Solfatara, $1,5.0$ & $5 / 18 / 40,7.1,0.33,19,0.32$ & $0.05,0.01,0.01$ & 2.0000 & Olson $^{[38]}$ \\
\hline South Haiwee, 5, 25.0 & $7 / 21 / 52,7.3,0.08,151,0.54$ & $0.64,0.11,0.08$ & 0.0200 & Swaisgood ${ }^{[53]}$ \\
\hline South Levee, $2,8.0$ & $10 / 17 / 89,7.1,0.33,18,0.32$ & $0.12,0.29,0.22$ & 0.5000 & Miller and Roycroft ${ }^{[31,32]}$ \\
\hline Sugatadani-Ike, 12.0 & $1 / 17 / 95,7.1,0.23,24,0.28$ & $0.54,0.20,0.18$ & 2.0000 & Uchida et $a l^{[56]}$ \\
\hline Surajbari, $4,8.0$ & $1 / 26 / 01,7.6,0.35,40,0.32$ & $0.12,0.10,0.09$ & 0.3000 & $\operatorname{EERI}^{[13]}$ \\
\hline Surgu, $8,55.0$ & $5 / 5 / 86,6.6,0.21,10,0.32$ & $0.72,0.15,0.14$ & 0.1500 & Ozkan et al. ${ }^{[39]}$ \\
\hline Suvi, $7,15.0$ & $1 / 26 / 01,7.6,0.42,37,0.32$ & $0.24,0.09,0.08$ & 1.1000 & Singh et al..$^{[50]}$ \\
\hline Takami, $8,120.0$ & $9 / 26 / 03,8.0,0.33,140,0.50$ & $1.31,0.37,0.31$ & 0.0010 & Nagayama et al..$^{[34]}$ \\
\hline Tapar, $7,15.5$ & $1 / 26 / 01,7.6,0.15,43,0.32$ & $0.21,0.12,0.07$ & 0.8000 & Singh et al..$^{[50]}$ \\
\hline Tejon storage, $5,11.0$ & $7 / 21 / 52,7.3,0.60,9,0.28$ & $0.45,0.19,0.16$ & 0.0100 & Seed et al $^{[48]}$ \\
\hline Tokachi Dike, 1, 6.0 & $9 / 27 / 03,8.1,0.40,125,0.70$ & $0.09,0.06,0.06$ & 2.0000 & UJNRPW\&SE ${ }^{[57]}$ \\
\hline Tokiwa, $7,33.5$ & $1 / 17 / 95,7.1,0.20,10,0.32$ & $0.49,0.20,0.16$ & 0.0010 & Matsumoto et al. ${ }^{[27]}$ \\
\hline Torish Dike 1, 1, 5.2 & $1 / 17 / 95,6.9,0.22,40,0.32$ & $0.15,0.05,0.04$ & 3.0000 & Ozutsumi et al..$^{[41]}$ \\
\hline Torishima Dike $2,1,5.5$ & $1 / 17 / 95,6.9,0.22,40,0.32$ & $0.14,0.07,0.07$ & 0.3000 & Ozutsumi et al..$^{[41]}$ \\
\hline Tsuboyama, $7,20.5$ & $10 / 23 / 04,6.8,0.13,19,0.32$ & $0.29,0.13,0.12$ & 0.0700 & Yasuda et $a l .{ }^{[55]}$ \\
\hline Upper crystal springs, $3,25.0$ & $4 / 18 / 06,7.6,0.80,2,0.40$ & $0.60,0.08,0.07$ & 0.0010 & Seed et al. ${ }^{[48]}$ \\
\hline Upper Howell, 3, 13.0 & $4 / 18 / 06,7.6,0.80,2,0.40$ & $0.60,0.18,0.15$ & 1.6000 & Seed et al $^{[188]}$ \\
\hline Upper San Fernando, 6, 25.0 & $2 / 9 / 71,6.6,0.45,11,0.32$ & $0.38,0.13,0.11$ & 0.9000 & Seed et $a l .^{[47]}$ \\
\hline Upper San Fernando, 6, 25.0 & $1 / 17 / 94,6.7,0.32,11,0.27$ & $0.46,0.11,0.11$ & 0.1500 & Bardet and Davis ${ }^{[4]}$ \\
\hline Vasona, $7,10.4$ & $10 / 17 / 89,7.0,0.40,9,0.32$ & $0.19,0.46,0.31$ & 0.0500 & Harder $^{[16]}$ \\
\hline Waste water plant, $2,4.5$ & $10 / 17 / 89,7.1,0.33,23,0.32$ & $0.08,0.50,0.45$ & 0.0200 & Miller and Roycroft ${ }^{[31,32]}$ \\
\hline Yamam regulatory, $7,27.2$ & $10 / 23 / 04,6.8,0.55,7,0.32$ & $0.38,0.10,0.09$ & 0.5000 & Yasuda et al..$^{[55]}$ \\
\hline Yumig., 4, 7.5 & $10 / 6 / 00,7.3,0.30,20,0.32$ & $0.13,0.07,0.06$ & 1.0000 & Matsuo $^{[28]}$ \\
\hline
\end{tabular}

(1): Dam types: 1: 1-zone levee, 2: Multi zone levee, 3: 1-zone earth dam, 4: 1-zone embankment, 5: 1-zone hydraulic fill dam; 6: Multi zone hydraulic fill; 7: Compacted multi zone dam; 8: Multi zone rock fill dam; 9 Concrete Faced Rock fill Dam (CFRD); 10: Concrete faced decomposed granite or gravel dam; 11: Natural slope; 12: Upstream constructed tailings dam; 13: Downstream constructed tailings dam; (2): $\mathrm{a}_{\max }$ values in italics indicate cases where ground motions were measured at dam site; (3): Displacements in italics indicate cases involving liquefaction

\section{MATERIALS AND METHODS}

Intuitively, crest settlement is expected to be influenced by the intensity of the earthquake (measured by peak ground acceleration), the strength of the materials within and underneath the embankment dam, the relationship between the fundamental period of the embankment dam and predominant period of the earthquake and the earthquake magnitude (quasi resonance). The methods used in this study to estimate or quantify these parameters and assess their influence on earthquake-related crest settlements are summarized in the following subsections.

Peak ground acceleration: The peak ground acceleration, $a_{\max }$, has been used in this study as a 518 
measure of the earthquake load intensity. The estimates for $a_{\max }$ were available from the references cited in Table 1. As indicated in Table 1, in only a few cases the earthquake accelerations were obtained from recorders located in close vicinity of the embankment or dam. Typically earthquake accelerations were estimated from attenuation relationships specifically developed for the earthquake considered in the reference and rarely from acceleration records from instruments installed near the dams or embankments.

Yield acceleration: Yield acceleration has been used in this study as a convenient, single-valued index of the shear strength of the material within and underneath the dam body. The parameter has been estimated following the sliding block approach as outlined below.

The stability assessment of the 152 case histories is based on the Newmark ${ }^{[35]}$ sliding block approach. This conceptual framework approximates the potential sliding mass as a rigid body resting on a rigid sloping base. The contact between the potential sliding mass and the underlying slope is assumed as rigid-plastic. In this approach, the potential sliding mass is considered to mobilize irreversibly in the down slope direction when ground acceleration in that direction exceeds the threshold required to overcome the cohesive-frictional resistance at the base of the sliding mass. For a single pulse of down slope earthquake acceleration, the instantaneous velocity of the sliding mass relative to the sloping base is obtained by integration of the difference between the earthquake acceleration and the mobility threshold with respect to time. When the magnitude of down slope earthquake acceleration drops back below the mobility threshold, the sliding mass would decelerate because of cohesive-frictional resistance and eventually may lose mobility. To obtain the magnitude of incremental, relative, down slope displacement of the sliding mass for the earthquake acceleration pulse that mobilized it, the instantaneous relative velocity is integrated against time. The total, relative, down slope displacement of the sliding mass is then estimated by summing up all such incremental relative displacements over the entire duration of earthquake.

The threshold acceleration above which the sliding mass is mobilized down slope, called the yield acceleration, is usually estimated from pseudo static slope stability analysis. The inertial effect due to the earthquake is typically accounted for by including the horizontal seismic coefficient, which when multiplied by the weight of the potential sliding mass (the volume of soil above the trial sliding surface and below slope face) provides a crude approximation of the average inertial force. Yield acceleration is taken to be equal to the horizontal seismic coefficient for which the factor of safety against slope instability is unity. Although the influence of the vertical component of earthquake-related ground motion is often neglected, this factor can be approximately accounted for by including a vertical seismic coefficient.

The pseudo static slope stability analysis is similar to static limit equilibrium slope stability assessment procedures except that the pseudo static procedure considers the inertial load during an earthquake on the potential siding mass usually by applying a single-valued horizontal acceleration sometimes referred to as the horizontal seismic coefficient. As in a static limit equilibrium analysis, the factor of safety is calculated against slope instability. The pseudo static analysis in this study was done with the help of slope stability software XSTABL ${ }^{[19]}$. The Simplified Bishop method was adopted in these computations. The soil properties used as inputs in these analyses were obtained as discussed in the following subsection.

In the first series of analyses, only the horizontal seismic coefficients were used. In the second series of analyses the vertical seismic coefficients were also included. Except for the few instances where the vertical as well as horizontal accelerograms were available at the site of the dam or embankment, the vertical seismic coefficients were assumed to be in proportion of the corresponding horizontal seismic coefficient depending on the distance of dam from the epicenter. The ratio between vertical and horizontal seismic coefficients was assumed to be 0.83 for a site to earthquake source distance of up to $10 \mathrm{~km}$ and a ratio of 0.33 was assumed for the distance of $100 \mathrm{~km}$. For intermediate distances the ratio was assumed based on linear interpolation between the values mentioned above.

Soil properties: In terms of the shear strength and unit weights, the database assembled in this study is reasonably well constrained. In approximately $75 \%$ of the case histories, the shear strength and unit weights of soil or rock fill within and underneath the embankment or dam body were estimated from site and material specific Standard Penetration Test (SPT) blow counts, $\left(\mathrm{N}_{1}\right)_{60}$, Cone Penetration Test (CPT) tip resistance, $\mathrm{q}_{\mathrm{c} 1}$. For the remaining cases material specific test data were not directly available. To analyze these dams, generic properties were used. Such uncertainties in the input soil parameters exist in many projects at the preliminary design stage as in Sigh et al. ${ }^{[50]}$.

For soils underneath water table, the pre- and postliquefaction shear strengths were estimated following Olson and $\mathrm{Stark}^{[37]}$ for soils characterized with 
normalized SPT blow count, $\left(\mathrm{N}_{1}\right)_{60}$, of up to 12 or normalized cone tip resistance, $\mathrm{q}_{\mathrm{c} 1}$, of up to $6.5 \mathrm{MPa}$. Soils with greater penetration resistance are considered non liquefiable. For non liquefiable soils, the shear strength was estimated using McGregor and Duncan ${ }^{[29]}$ where penetration data were available unless the parameters were directly available from the case history reference. Range of shear strength and other input parameters associated with different types of dam, embankment or foundation materials are listed in the Table 1.

Dam fundamental (elastic) period: The fundamental (elastic) period, $T_{D}$, of the embankment-foundation system is estimated using the framework proposed by Gazetas and Dakoulas ${ }^{[15]}$ for isotropic linear elastic embankments within a valley. For embankment dams, rockfill dams and CFRDs, valley geometry between narrow and wide trapeziums was assumed. For highway and railway embankments, river dikes and tailings dams the embankment was assumed to be infinitely long. The analytical expression for the fundamental period of an infinitely long dam or embankment, $\mathrm{T}_{\mathrm{d} \infty}$, measured in second is given by:

$\mathrm{T}_{\mathrm{d} \infty}=2.61 \mathrm{H} / \mathrm{V}_{\mathrm{s}}$

Where:

$\mathrm{H}=$ The height of the dam or embankment in meter $\mathrm{V}_{\mathrm{s}}=$ The shear wave velocity in meter per second

The chart used for this purpose is shown in Fig. 1 for embankments or dams with crest lengths of up to ten times their maximum heights. In essence, the relationship shown in Fig. 1 represents valley geometry between narrow and wide trapeziums. Dams or embankments with crest length exceeding ten times the maximum height were considered to be infinitely long.

Shear wave velocity required as an input in Eq. 1 is estimated using the following empirical relationship ${ }^{[2]}$ :

$\mathrm{V}_{\mathrm{s}}=93.2 \times\left(\mathrm{N}_{1}\right)_{60}{ }^{0.231}$

where, $\left(\mathrm{N}_{1}\right)_{60}$ is the normalized SPT blow count representative of the dam body materials.

Earthquake predominant period: In most of the cases, the predominant period of the earthquake ground motion, $\mathrm{T}_{\mathrm{p}}$, were estimated as per the Idriss $^{[18]}$ guidelines. In a few instances, predominant period of earthquake ground motion, $\mathrm{T}_{\mathrm{p}}$, was reported in the references based on acceleration records from strong motion instruments at dam sites.

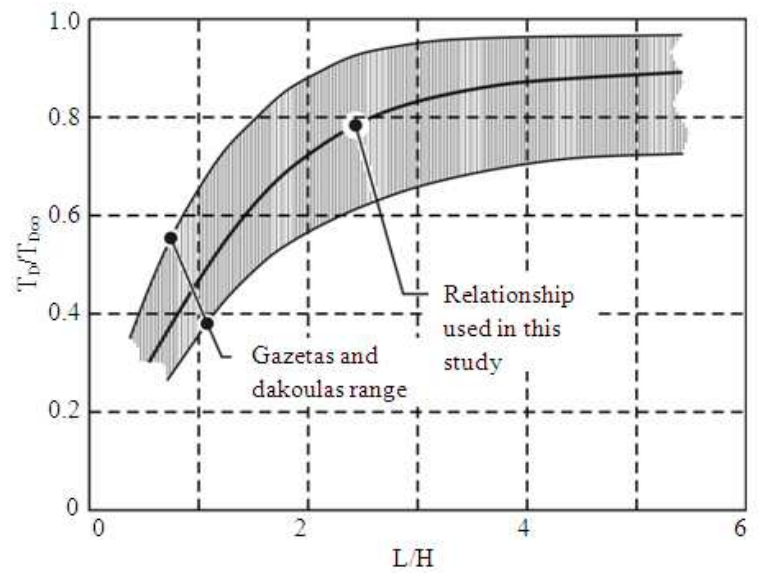

Fig. 1: Estimation of fundamental period

Parameters: If the parameters can be combined to obtain dimensionless hybrids based on simple physical considerations, assessment of parametric influence on crest settlement is expected to become convenient. Two such hybrid parameters are introduced in the following paragraphs. The extent of influence of two additional parameters, earthquake magnitude and the vertical component of ground motion, on crest settlement is also examined.

The crest settlement is expected to relate negatively to the shear strength of material within and underneath the embankment dam and positively to the ground motion amplitude. To assess the joint influence of the shear strength of material within and underneath the embankment dam and the ground motion amplitude on crest settlement the ratio of yield acceleration and peak horizontal acceleration, $\mathrm{a}_{\mathrm{y}} / \mathrm{a}_{\max }$, has been used following Hynes-Griffin and Franklin ${ }^{[17]}$.

Secondly, in the events when the fundamental period of the embankment or dam is approximately equal to the predominant period of the earthquake, the impact of the earthquake is expected to be magnified because of quasi resonance. It therefore appears that crest settlements may depend on the ratio, $T_{D} / T_{p}$. The influence of this ratio on the crest settlement has also been studied.

\section{RESULTS}

The analytical results and observed crest settlements are listed in Table 1. Simple interpretation of these results is presented in the following subsections.

Material shear strength and horizontal component of ground motion: The observed crest settlements from Table 1, $\Delta$, are plotted $\mathrm{a}_{\mathrm{y}} / \mathrm{a}_{\max }$ in Fig. 2. 520 
Am. J. Engg. \& Applied Sci., 2 (3): 515-525, 2009

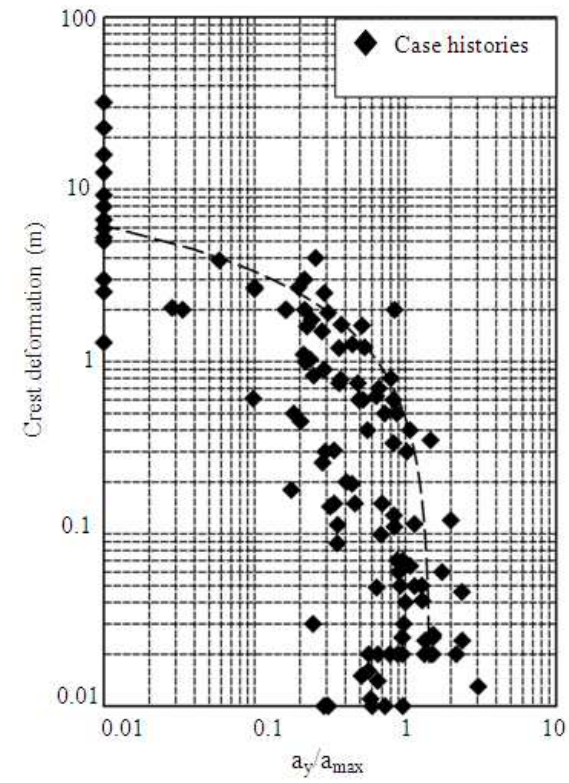

Fig. 2: $\Delta-\mathrm{a}_{\mathrm{y}} / \mathrm{a}_{\max }$ relationship without considering vertical ground acceleration

Although there is a considerable scatter in the data, there appears to be a strong negative relationship between $\Delta$ and $\mathrm{a}_{\mathrm{y}} / \mathrm{a}_{\max }$. These results also provide a useful practical guidance by demonstrating that the likelihood of large crest settlements becomes small if the yield acceleration exceeds about 1.3 times the peak horizontal ground acceleration. Figure 2 also shows that the crest settlement sharply decreases as $a_{y} / a_{\max }$ exceeds 0.6 and becomes smaller than 0.2 as $a_{y} / a_{\max }$ exceeds unity. Also, the crest settlement could exceed $1 \mathrm{~m}$ if $\mathrm{a}_{\max }$ was to exceed about 1.3 times the yield acceleration. These observations are consistent with the intuition that as the material within and underneath the embankment becomes strong relative to the intensity of earthquake load, the crest settlement tends to decrease.

It should be noted that the analyses upon which these inferences are based are physically simplistic. Also, there is a considerable scatter in the results shown in Fig. 2 with the correlation shown on the plot roughly representing the upper bound values of crest settlements. Thus, the correlation of Fig. 2 should not be viewed as a precise estimator of crest settlement; it, in essence, is an inexpensive tool that gives a reasonably conservative estimate of the crest settlements for an embankment dams under earthquake loading. The possibility of explaining the scatter by the differences in the peak vertical ground acceleration (i.e., whether the event is near field or far field), the earthquake magnitude (i.e., duration of earthquake) and the proximity of the fundamental period of the embankment dam and the predominant period of the earthquake is examined below.

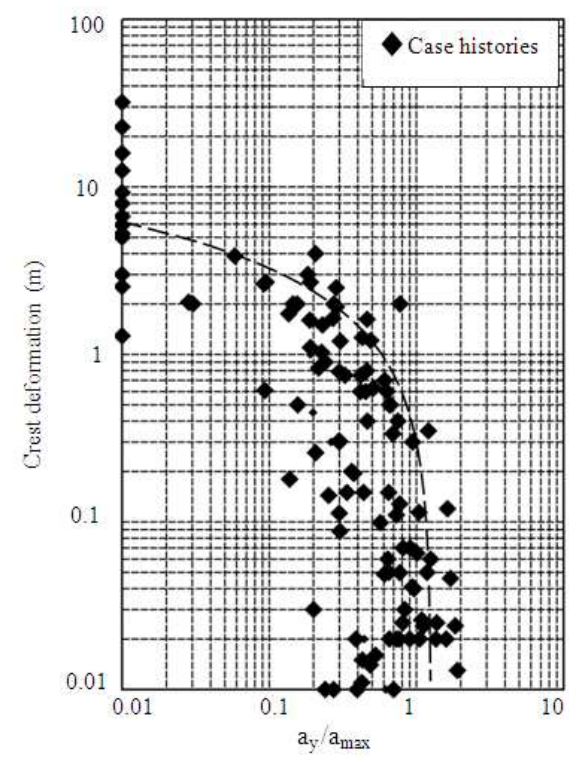

Fig. 3: $\Delta-\mathrm{a}_{\mathrm{y}} / \mathrm{a}_{\max }$ relationship considering vertical ground acceleration

Vertical component of ground motion, earthquake magnitude, predominant period of earthquake and fundamental period of embankment dam: To examine whether peak vertical ground acceleration explains the scatter, the results of analyses which included the peak vertical ground acceleration are shown in Fig. 3. A comparison of these results with Fig. 2 shows that inclusion of vertical ground acceleration does not improve the reliability in the prediction of crest settlement based on $a_{y} / a_{\max }$. It appears therefore that peak vertical ground acceleration does not explain the scatter in the $a_{y} / a_{\max }-\Delta$ data.

The variation of $\Delta$ with magnitude, $\mathrm{M}_{\mathrm{w}}$, Fig. 4, shows although there is a minor increasing trend $\Delta$ with increasing $\mathrm{M}_{\mathrm{w}}$, the influence of $\mathrm{M}_{\mathrm{w}}$ on $\Delta$ may not be significant. Therefore, $\mathrm{M}_{\mathrm{w}}$ does not appear to explain the scatter in the $a_{y} / a_{\max }-\Delta$ data.

The variation of $\Delta$ against $\mathrm{T}_{\mathrm{D}} / \mathrm{T}_{\mathrm{p}}$, Fig. 5 , shows that $\Delta$ decreases significantly as the ratio, $\mathrm{T}_{\mathrm{D}} / \mathrm{T}_{\mathrm{p}}$, becomes larger than 2. For smaller values of $T_{D} / T_{p}$ the ratio does not appear to have a significant influence on $\Delta$. Therefore variation in $\mathrm{M}_{\mathrm{w}}$ also appears to account for the scatter in the $a_{y} / a_{\max }-\Delta$ data partially.

Suggested use of the results: The relationship between $\mathrm{a}_{\mathrm{y}} / \mathrm{a}_{\max }$ and $\Delta$ shown in Fig. 2 is based on simplified assumptions regarding material behavior implicit in the pseudostatic and sliding block frameworks. These assumptions are by themselves likely to be major contributors to the scatter in the results shown in Fig. 2. 


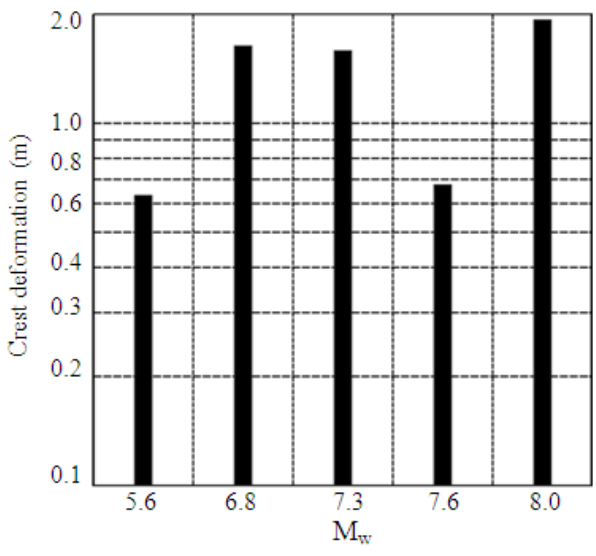

Fig. 4: Influence of $\mathrm{M}_{\mathrm{w}}$ on crest settlement

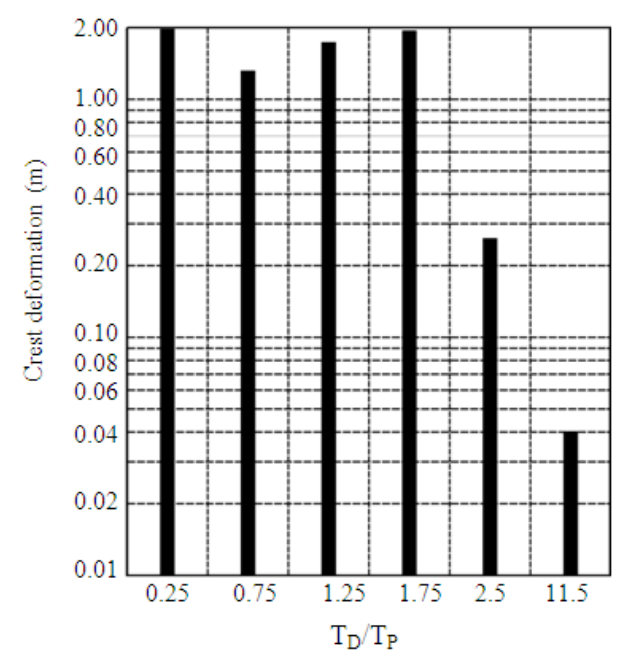

Fig. 5: Influence of $T_{D} / T_{P}$ on crest settlement

Approximation of the earthquake load intensity with peak ground acceleration and the imprecision in the relationships of Eq. 1 and 2 used to estimate the fundamental period of embankment dam and shear wave velocity, respectively, are also expected to contribute to the uncertainty in the $a_{y} / a_{\max }-\Delta$ correlation.

Since it is difficult to quantify these uncertainties, a more sophisticated statistical treatment of the results was not considered necessary. Further analysis of the results using a soft computation tool, e.g., the artificial neural network or the fuzzy logic framework, is also unlikely to enhance the practical usefulness of the procedure proposed in this article because of the conceptual simplifications of the analytical model used in this study.

Although the uncertainty in the proposed $a_{y} / a_{\max }-\Delta$ relationship limits its potential as a detailed engineering tool, the relationship is expected to be useful in several practical problems. The $a_{y} / a_{\max }-\Delta$ correlation, for instance, could be used as an inexpensive tool for assessing retrofit requirement of an existing embankment dam or for quick estimation of freeboard requirement of an embankment dam in the early planning stage.

\section{DISCUSSION}

The objective of this article was to identify the main parameters that influence earthquake-related crest settlements of embankment dams and first-order quantification of their influence on crest settlement. Observed performance of earth dams and embankments in 152 instances of earthquake loading was considered for the purpose.

The results of the study indicate that the ratio of yield acceleration and peak horizontal ground acceleration, $\mathrm{a}_{\mathrm{y}} / \mathrm{a}_{\max }$, has a strong influence on earthquake-related crest settlement, $\Delta$. An approximate correlation between $\mathrm{a}_{\mathrm{y}} / \mathrm{a}_{\max }$ and $\Delta$ has been derived from these results indicated that crest settlement sharply decreases as $a_{y} / a_{\max }$ exceeds 0.6 and becomes smaller than 0.2 as $\mathrm{a}_{\mathrm{y}} / \mathrm{a}_{\max }$ exceeds 1.0. The crest settlement could exceed $1 \mathrm{~m}$ if $\mathrm{a}_{\max }$ was to exceed about 1.3 times the yield acceleration. Although there is a considerable scatter in the $a_{y} / a_{\max }-\Delta$ data, which prevents the use of the relationship as a detailed engineering tool, it is believed that the relationship could be used as an easy and inexpensive screening tool in the preliminary design stage of a proposed embankment dam or in resource planning for a dam retrofit project. The conceptual simplicity of the analytical procedure used in this study is likely to be a major contributor to the scatter in the $a_{y} / a_{\max }-\Delta$ data. Since the uncertainty in the $a_{y} / a_{\max }-\Delta$ relationship on this count is not easily quantifiable, the data were not subjected to a rigorous and elaborate treatment for developing a more precise estimator of earthquake-related crest settlement.

The influence of $T_{D} / T_{p}, M_{w}$ and the vertical component of ground motion on crest settlements were also assessed. These assessments indicated that the crest settlements are insensitive to $T_{D} / T_{P}$ for $T_{D} / T_{p} \leq 2$ but there is a sharp decrease in crest settlement as $T_{D}$ exceeds $2 T_{p}$. The influence of $M_{w}$ was found to be less remarkable and only a small increase in the crest settlement was apparent with increasing earthquake magnitude. The influence of vertical acceleration on crest settlement also appeared to be minor. Consequently, there appears to be no added benefit in including the vertical component of ground motion in pseudo static slope stability analysis. 
To summarize, a detailed evaluation of earthquake induced crest settlement is only appears to be needed if (a) $\mathrm{a}_{\mathrm{y}} / \mathrm{a}_{\max }$ exceeds 1 or (b) $\mathrm{T}_{\mathrm{D}} \leq 2 \mathrm{~T}_{\mathrm{p}}$.

\section{CONCLUSION}

Performance records of embankments and dams from past earthquakes indicate that there is a strong correlation between $a_{y} / a_{\max }$ and crest settlement. Crest settlement also appears to depend on $\mathrm{T}_{\mathrm{D}} / \mathrm{T}_{\mathrm{P}}$ and marginally on earthquake magnitude.

\section{REFERENCES}

1. Abdel-Ghaffar, A.M. and R.F. Scott, 1979. Analysis of earth dam response to earthquakes. J. Geotech. Eng., 105: 1379-1404. http://cedb.asce.org/cgi/WWWdisplay.cgi?5015033

2. Andrus, R.D. and K.H. Stokoe, 2000. Liquefaction resistance of soils from shear-wave velocity. J. Geotech. Geoenviorn. Eng., 126: 1015-1025. DOI: 10.1061/(ASCE)1090-0241(2000)126:11(1015)

3. Arrau, L., Ibarra, I. and G. Noguera, 1985. Performance of Cogoti Dam Under seismic Loading. In: Concrete Face Rockfill Dams-Design, Construction and Performance, Barry Cooke, J. and J.L. Sherard (Eds.). ASCE., ISBN: 0872625036, pp: 1-14.

4. Bardet, J.P. and C.A. Davis, 1996. Performance of San Fernando dams during 1994 Northridge earthquake. J. Geotech. Geoenviorn. Eng., 122: 554-563. DOI: 10.1061/(ASCE)0733-9410(1996)122:7(554)

5. Boulanger, R.W., J.D. Bray, S.M. Merry and L.H. Mejia, 1995. Three-dimensional dynamic response analysis of Cogswell dam. Can. Geotech. J., 32: 452-464. DOI: 10.1139/t95-048

6. Bureau, G., R.L. Volpe, W.H. Roth and T. Udaka, 1985. Seismic Analysis of Concrete face Rockfill Dams. In: Concrete Face Rockfill Dams-Design, Construction and Performance, Barry Cooke, J. and J.L. Sherard (Eds.). ASCE., ISBN: 0872625036, pp: 479-508.

7. Chaney, R.C., 1979. Earthquake induced deformation in earth dams. Proceeding of the 2 nd US National Conference on Earthquake Engineering, pp: 633-642.

8. Choggang, S., 1988. Some experiences from damages of embankments during strong earthquakes in China. Proceeding of the 2nd International Conference on Case Histories in Geotech. Earthquake Engineering, pp: 729-735.

9. De Alba, P.A., H.B. Seed, E. Retamal and R.B. Seed, 1988. Analyses of dam failures in 1985 Chilean earthquake. J. Geotech. Eng., 114: 1414-1434. DOI: 10.1061/(ASCE)0733-9410(1988)114:12(1414)
10. Dobry, R. and L. Alvarez, 1967. Seismic failures of Chilean tailings dams. J. Soil Mech. Found. Div., 93: 237-260.

11. Elgamal, A.W., R.F. Scott and M.F. Succarieh, 1990. La Villita dam response during five earthquakes including permanent deformation. J. Geotech. Eng., 114: 1443-1462. DOI: 10.1061/(ASCE)0733-9410(1990)116:10(1443)

12. Earthquake Engineering Research Institute, 1997. Some observation on engineering aspects of the Jabalpur earthquake of 22 May, 1997. http://nicee.org/eqe-iitk/uploads/EQR_Jabalpur.pdf

13. Earthquake Engineering Research Institute, 2001. The Republic Day (Bhuj) earthquake of Kachchh and active faults, Gujarat, western India. Reconnaissance report. EERI, Oakland, CA, USA. http://sciencelinks.jp/jeast/article/200123/000020012301A0929620.php

14. Earthquake Engineering Research Institute, 2004. Preliminary observation on the Al Hoceima Morocco earthquake of 24 February, 2004. Special report. EERI, Oakland, CA, USA. http://www.eeri.org/lfe/pdf/morocco_alhoceima_ee ri_preliminary_report.pdf

15. Gazetas, P. and P. Dakoulas, 1992. Seismic analysis and design of rockfill dams. Soil Dyn. Earthquake $\quad$ Eng., 11: 27-61. http://cat.inist.fr/?aModele $=$ afficheN\&cpsidt $=4731$ 618

16. Harder Jr., L.H., 1991. Performance of earth dams during Loma Prieta earthquake. US Geological Survey Professional Paper, 1552: 3-26. http://cat.inist.fr/?aModele $=$ afficheN\&cpsidt $=9984$ 042

17. Hynes-Griffin, M.E. and A.G. Franklin, 1984. Rationalizing the seismic coefficient method. Miscellaneous Paper: GL-84-13, US Army Corps of Engineers Waterways Experiment Station, Vicksburg, Mississippi.

http://oai.dtic.mil/oai/oai?verb=getRecord\&metada taPrefix $=$ html\&identifier $=$ ADA144730

18. Idriss, I.M., 1991. Earthquake ground motions at soft soil sites. Proceeding of the 2 nd International Conference on Recent Advances in Geotech. Earthquake Engineering and Soil Dynamics, Mar. 11-15, St. Louis, Missouri, pp: 2265-2272. http://nisee.berkeley.edu/elibrary/Text/LIB050207

19. Interactive Software Designs, Inc., 1994. XSTABL: An integrated slope stability analysis program for personal computers. Reference Manual. Interactive Software Designs, Inc., Moscow, Idaho, USA. 
20. Ishihara, K., S. Yasuda and Y. Yoshida, 1990. Liquefaction-induced flow failure of embankments and residual strength of silty sands. Soils Found., 30: 69-80. http://ci.nii.ac.jp/naid/110003959719/ja

21. Ishihara, K., S. Okusa, N. Oyagi and A. Ischuk, 1990. Liquefaction-induced flow slide in the collapsible loess deposit in Soviet Tajik. Soils Found., 30: 73-89. http://ci.nii.ac.jp/naid/110003959974/en

22. Iwashita, T., N. Yasuda, A. Nakamura and O. Takeda, 1995. Dynamic analysis of rockfill dams considering frequency dependent characteristics of radiation damping ratio. Proceeding of the $1 \mathrm{st}$ International Conference on Earthquake Geotech. Engineering, pp: 511-516.

23. Krinitzsky, E.L. and M.E. Hynes, 2002. The Bhuj, India, earthquake: Lessons learned for earthquake safety of dams on alluvium. Eng. Geol., 66: 163-196. DOI: 10.1016/S0013-7952(02)00049-2

24. Lai, S.S. and H.B. Seed, 1980. Dynamic response of long valley dam in the Mammoth lake earthquake series of May 25-27 1980. Report 85/12, Univ. of Calif., Berkeley. http://nisee.berkeley.edu/documents/EERC/EERC85-12.pdf

25. Lingyao, L., L. Kueifen and B. Dongping, 1980. Earthquake damage of Baihe earth dam and liquefaction characteristics of sand and gravel materials. Proceeding of the 7th World Conference on Earthquake Engineering, Istanbul, pp: 171-178.

26. Makdisi, F.I. and H.B. Seed, 1978. Simplified procedure for estimating dam and embankment earthquake-induced deformations. J. Geotech. Eng., 104: 849-867. http://cedb.asce.org/cgi/WWWdisplay.cgi?5013898

27. Matsumoto, M., A. Nakamura, T. Sasaki and T. Iwashita, 1996. Effects on Dams. Soil Found., 36: 273-281. http://ci.nii.ac.jp/naid/10016595629

28. Matsuo, O., 2000. Report on the Western Tottori Prefecture earthquake of October 6, 2000. In: Report of 33rd Tech. of US-Japan Natural Resources Development Program, Japan. http://www.jstage.jst.go.jp/article/seisankenkyu/52/ 12/52_590/_article

29. McGregor, J.A. and J.M. Duncan, 1998. Performance and use of standard penetration tests I geotechnical engineering practice. Report of Virginia Tech Center for Geotech. Practice and Research.

30. Mishima, S. and H. Kimura, 1970. Characteristics of landslides and embankment failures during the Tokachioki earthquake. Soils Found., 10: 39-51. http://ci.nii.ac.jp/naid/110003899025/
31. Miller, E.A. and G.A. Roycroft, 2004. Seismic Performance and Deformation of Leeves: Four case studies. J. Geotech. Geoenviorn. Eng., 130: 344-354. DOI: 10.1061/(ASCE)1090-0241(2004)130:4(344)

32. Miller, E.A. and G.A. Roycroft, 2004. Compaction grouting test program for liquefaction control. J. Geotech. Geoenviorn. Eng., 130: 355-361. DOI: 10.1061/(ASCE)1090-0241(2004)130:4(355)

33. Miura, K., N. Yoshida and K. Wakamatsu, 1995. "Damage to fill embankment during the 1993 Kushiro-oki earthquake. Proceeding of the 1st International Conference on Earthquake Geotech. Engineering, pp: 1057-1062. ISBN: 905410578X

34. Nagayama, I., Y. Yamaguchi, T. Sasaki, A. Nakamura, H. Kawasaki and D. Hirayama, 2004. Damage to dams due to three large earthquake occurred in 2003, in Japan. US-Japan Natural Resources Development Program, Japan. http://www.pwri.go.jp/eng/ujnr/joint/36/paper/63na gaya.pdf

35. Newmark, N.M., 1976. Effects of earthquakes on dams and embankments. Géotechnique, 15: 139-160. http://nisee.berkeley.edu/elibrary/Text/2006091413

36. Okusa, S. and S. Anma, 1980. Slope failures and tailings dam damage in the 1978 Izu-OhshimaKinkai earthquake. Eng. Geol., 16: 195-224. DOI: 10.1016/0013-7952(80)90016-2

37. Olson, S.M. and T.D. Stark, 2003. Yield strength ratio and liquefaction analyses of slopes and embankments. J. Geotech. Geoenviorn. Eng., 129: 727-737. DOI: 10.1061/(ASCE)10900241(2003)129:8(727)

38. Olson, S.M. 2001. Liquefaction analysis of level and sloping ground using field case histories and penetration resistance. PhD Dissertation, University of Illinois, Urbana-Champaign. https://netfiles.uiuc.edu/olsons/www/olson_thesis.pdf

39. Ozkan, M.Y., M. Erdik, M.A. Tuncer and C. Yilmaz, 1996. An evaluation of Surgu dam response during 5 May 1986 earthquake. Soil Dyn. Earthquake Eng., 15: 1-10. DOI: 10.1016/02677261(95)00030-5

40. Ozutsumi, O., S. Sawada, S. Iai, Y. Takeshima, W. Sugiyama and T. Shimazu, 2002. Effective stress analysis of liquefaction-induced deformation in river dikes. Soil Dyn. Earthquake Eng., 22: 1075-1082. DOI: 10.1016/S0267-7261(02)00133-1

41. Pender, M.J. and T.W. Robertson, 1987. Edgecumbe earthquake: Reconnaissance report. Bull. N. Z. Natl. Soc. Earthquake Eng., 20: 201-249.

42. Rai, D.C. and C.V.R. Murty, 2003. North Andaman (Diglipur) earthquake of 14 September 2002. India. http://nicee.org/eqeiitk/uploads/EQR_Andaman.pdf 
43. Resendiz, D., Romo, M.P. and E. Moreno, 1982. El infiernillo and la villita dams: Seismic behavior. J. Geotech. $\quad$ Eng., 108 : 109-131. http://cedb.asce.org/cgi/WWWdisplay.cgi?8200034

44. Sakamoto, S., H. Yoshida, Y. Yamaguchi, H. Satoh, T. Iwashita and N. Matsumoto, 2002. Numerical simulation of sliding of an earth dam during the 1985 Kobe earthquake. Proceeding of the 3rd USJapan Workshop on Advanced Research on Earthquake Engineering for Dams, June 22-23, San Diego, $\quad$ California, pp: 416. http://www.stormingmedia.us/68/6857/A685714.html

45. Sarma, S.K. 1975. Seismic stability of earth dams and embankments. Géotechnique, 25: 743-761.

46. Sasaki, Y., K. Tamura, M. Yamamoto and J. Ohbayashi, 1995. Soil improvement work for river embankment damaged by the 1993 Kushiro-Oki earthquake. Proceeding of the 1st International Conference on Earthquake Geotech. Engineering, pp: 43-48. http://river.ceri.geo.jp/itiran/h7/h7-189202.pdf

47. Seed, H.B., K.L. Lee, I.M. Idriss and F.I. Makdisi, 1975. The slides in the San Fernando dams during the earthquake of February 9, 1971. J. Geotech. Geoenviorn. Eng., 101: 651-688. http://cedb.asce.org/cgi/WWWdisplay.cgi?5011449

48. Seed, H.B., I.F. Makdisi and P. De Alba, 1978. Performance of earthen dams during earthquakes. J. Geotech. $\quad$ Eng., $\quad$ 104: 967-994. http://cedb.asce.org/cgi/WWWdisplay.cgi?5013870

49. Singh, R., D. Roy and D. Das, 2007. A correlation for permanent earthquake-induced deformation of earth embankments. Eng. Geol., 90: 174-185. DOI:10.1016/J.ENGGEO.2007.01.002

50. Singh, R., D. Roy and S.K. Jain, 2005. Analysis of earth dams affected by the 2001 Bhuj earthquake. Eng. Geol., 80: 282-291. DOI:10.1016/J.ENGGEO.2005.06.002

51. Sitar, N., 1995. Geotechnical Reconnaissance of the effect of January 17, 1995 Hyogoken Nambu earthquake Japan. Report of EERC No. 95/01, University of Berkeley, USA. http://library.eerc.berkeley.edu/archives/kobe/EER C-95-01/

52. Stroitel, G., 1969. Design and investigation of seismically stable dams in Japan. Power Technol. Eng. (Formerly Hydrotech. Construct.), 3: 946-955. DOI: $10.1007 / \mathrm{BF} 02395813$
53. Swaisgood, J.R., 2003. Embankment dam deformations caused by earthquakes. Paper No. 14. http://db.nzsee.org.nz/PCEE/2003/View/Paper014s .pdf

54. Tani, S., 2000. Behavior of large fill dams during earthquake and earthquake damage. Soil Dyn. Earthquake Eng., 20: 223-229. DOI: 10.1016/S0267-7261(00)00055-5

55. Yasuda, N., M. Kondo, T. Sano, H. Yoshioka, Y. Yamaguchi, T. Sasaki and M. Tomita, 2005. Effect of the mid Niigata prefecture earthquake in 2004 on dams. US Japan Natural Resources Development Program, Technical Report. http://www.pwri.go.jp/eng/ujnr/joint/37/paper/a3ya suda.pdf

56. Uchida, K., T. Torri, T. Tsujino, S. Ando, K. Higasio and T. Yamamoto, 2001. A study of failure mechanism of embankment dam for irrigation damaged by the 1995 Hyogoken Nambu earthquake. Proceeding of the 4th Internatioanl Confernece on Recent Advances in Geotech. Earthquake Engineering.

57. UJNR Panel on Wind and Seismic Effects, 2003. Report on the 26 September, 2003 Tokachi-Oki Earthquake, Japan, http://www.pwri.go.jp/eng/ujnr/newnl/enl_4.pdf

58. Yegian, M.K., E.A. Marciano and V.G. Ghahraman, 1991. Earthquake-induced permanent deformations: Probabilistic approach. J. Geotech. Eng., 117: 35-50. http://cat.inist.fr/?aModele $=$ afficheN\&cpsidt $=1953$ 3632

59. Yegian, M.K., V.G. Ghahraman and R.N. Harutinunyan, 1994. Liquefaction and embankment failure case histories, 1988 Armenia earthquake. J. Geotech. Eng., 120: 581-596. DOI: 10.1061/(ASCE)07339410(1994)120:3(581)

60. Yan, L., 1991. Seismic deformation analysis of earth dams: a simplified method. Report of Calif. Institute of Tech., Calif., Report SML 91-01. http://caltecheerl.library.caltech.edu/272/00/SML9 101.pdf 